\title{
Islamic Character Education in E-Learning Model: How Should It be Implemented?
}

\author{
Mutmainnah Mustofa, Rulam Ahmadi, Imam Wahyudi Karimullah \\ University of Islam Malang, East Java, Indonesia \\ Email corresponding author: inamustofa@unisma.ac.id
}

\begin{abstract}
Recently, studies examining the inclusion of Islamic character education in schooling sectors have been exclusively discerned. The research mainly focused on teachers' and students' perceptions, curriculum and materials development, as well as policy implementation. Albeit the results of these studies shared significant insights in teacher education programs, very sparse discussions were carried out with regard to how the Islamic character education should be enacted. Interestingly, virtual education nowadays also challenges the implementation of this notion. In this work, therefore, we propose a model of Islamic character education cultivation employing e-learning approach in a schooling context. The use of participatory action research (PAR), additionally, is encouraged to capture learning cycles of Islamic character in the classroom between teachers and students. This proposal, if implemented by teachers, would contribute to better realization of moderate teachings of Islam through character education.
\end{abstract}

Keywords: Islamic character education, PAR, e-learning, school

\section{INTRODUCTION}

Globalization affects rapidly changing dimensions in every sectors of human life, including in the education institution. Teachers in many schools around the world are now altering their conventional teaching method to the new emerging technology-enhanced teaching by utilizing online learning media effectively to support their students' learning engagement (Kaufhold, Bayer, \& Reuter, 2020; Vie, 2018). This has brought to the realization that education is nowadays cannot be separated from technology.

E-learning is one, among other terms, platform geared by this development (Choudhury \& Pattnaik, 2020; Mayer, 2019; Tongkaw, 2013). In this platform, teaching and learning are mostly done virtually, and the interaction of teachers and students do not always take place inside the classroom. Besides, e-learning is potential to cultivate students' autonomous learning through this virtual enactment. Through this online interaction, both teachers and students are engaged collaboratively to negotiate their meaning in a given tasks.

A number of studies have been carried out to uncover the potentials of e-learning in educational sectors. In Iran, for instance, Talebian, Mohammadi, \& Rezvanfar ( 2014) suggested that e-learning encompasses easy access, equity, flexibility, and group collaboration enhancement for both teachers and students. In Turkey, Kimiloglu, Ozturan, \& Kutlu (2017) elaborated that e-learning platform is perceived as convenient, leading to extending selfmotivation for teachers and learners. This idea is confirmed by (Zainuddin, 2018) in Malaysian schooling contexts. In his work, Zainuddin explored the students' engagement and motivation construction in e-learning process.

In the Indonesian educational settings, e-learning activities have been massively conducted. It is because the Ministry of Education (MoE) of Indonesia believed that the country development in education sectors should be aligned with the world advances of technology, thus leading to empowering e-learning in school levels (Zainuddin, 2018). In the vocational level, for 
instance, Triyono (2015) have found that teachers in Vocational High School engaged actively in materials construction using e-learning platform. Anchored by the idea of gamification in learning, Sari, Fadillah, Jonathan, \& David Prabowo, (2019) tested their e-learning application which employ Smartphone - to support blind children learning engagement. In their study, the students found this application useful and convenient if compared to the traditional learning activities.

Given the convenience of e-learning entails in education, there is an awareness to integrate Islamic character education within the practice of e-learning in the Indonesian schooling sectors (Wibawa \& Purwarianti, 2016). Memon (2011) asserts that it is central for Islamic teachers to navigate Islamic education which corresponds to the globalized world by maintaining character education in the curriculum. The idea of teaching Islamic character education in the Islamic schooling as suggested by Memon portrays various assumptions. One of them is to enable Islamic schools to compete with public schools which have been standardized. Scholars hold dissimilar perspectives of Islamic character education. For instance, Halim Tamuri (2007) named it as teaching akhlaq (moral values). Meanwhile, other scholars do not have an agreed definition for this notion. In essence, the Islamic education character is a term used to describe norms and values pertaining to Islamic ethical understandings (Memon, 2011; Saada \& Gross, 2017).

In response to this initiative, we have explored that scant publications are written to document how to incorporate Islamic character education within e-learning platforms (Saada \& Gross, 2017) in schooling sectors. To fill this void, we put forward a model for teaching Islamic character education viewed from our reflections. These contemplations are derived from our intensive face-to-face meetings, classroom observations, and in-depth interviews with pre-school teachers in Malang, East Java, Indonesia. These teachers were invited to attend a teacher professional development workshop dedicated to navigating Islamic character education in the Indonesian schooling contexts.

\section{THE MODEL}

\section{Cycle of Teaching Islamic Character Education}

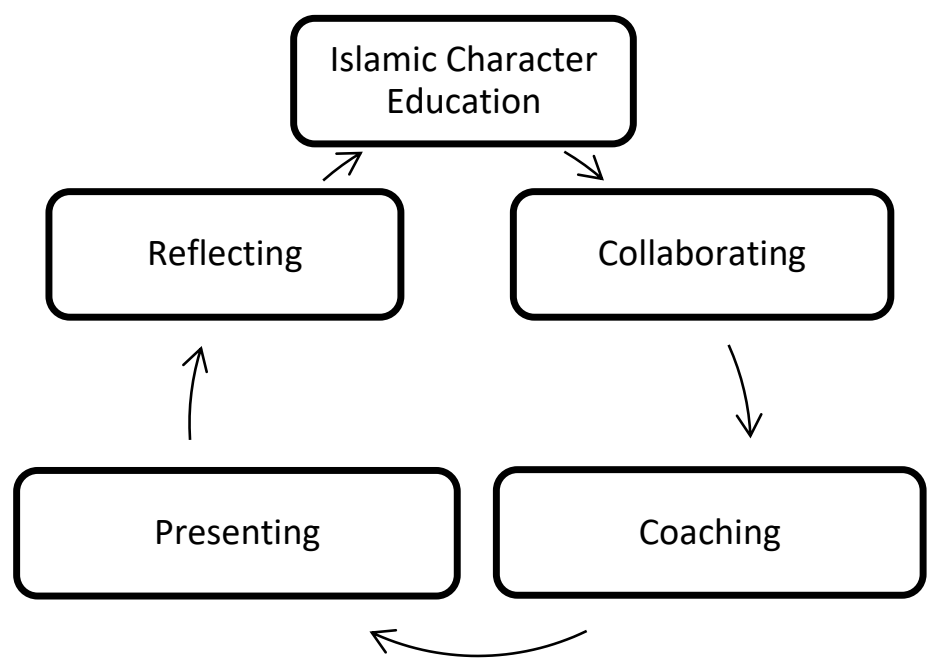

This model is anchored by the idea of Saada \& Gross (2017) which sees principles of Islamic character education as potential theories to be included in the curriculum in schooling sectors. It starts by putting the notion of Islamic character education on top of students' shared goals. The 
objective is to lead the students to understanding that values and attitudes are central for their social interactions (Yang, 2018).

In addition to locating the Islamic character education on top the Model, we decide to use the term Collaborating for the next learning cycle. In this stage, by using e-learning platforms (i.e. Facebook), students can be assigned to make Peer Facebook Activity (PFA). Lin (2018) supported the use of Peer Facebook activity in learning engagement since this platform allows for effective peer feedback, peer mentoring, and peer assessment among the students.

To persist this collaboration, the teachers need to carry out coaching. In this respect, the students can consult to the teachers about their understandings of the topic discussed in the classroom. According to Stoetzel \& Shedrow (2020), this coaching encompasses authentic realization of certain complexities that the students face in the learning process. Coaching, as suggested by scholars, can be carried out using several e-learning platforms such as online learning websites.

Furthermore, the model then proposes presenting activity as a channel for the students to cross-check their understandings of topics with their peers. We include this term as practical enactment in student-student interaction. The benefit entailed in presenting activity covers the students' awareness to monitor their learning after being commented by their peers (Trainor, 2012).

Lastly, reflecting is put at the end of the learning cycle. This aims at recalling and remembering activities done in the previous three stages. Reflection is a part of echoing students learning engagement (Pai, Ko, Eng, \& Yen, 2017). In this model, these four stages lead to students' understanding of Islamic character education in the forms of collaboration, selfawareness, respecting each other, and self-engagement.

\section{CONCLUSION}

In this proposal, we model how to integrate the Islamic character education values using elearning platforms. The examples provided in this paper are not limited, and thus, other scholars are encouraged to employ more various platforms of e-learning in their research and teaching practices. We also have outlined several facts why this proposal is central to be applied by teachers, particularly in the Indonesian schooling contexts. To add the discussion and further elaboration of this model, we encourage more investigations from researchers on using the model in the classroom. For instance, the deployment of Participatory Action Research (PAR) to generate negotiation on learning materials is worth-doing. PAR is believed to effective if applied in this model.

\section{REFERENCES}

Choudhury, S., \& Pattnaik, S. (2020). Emerging themes in e-learning: A review from the stakeholders' perspective. Computers \& Education, 144, 103657. https://doi.org/10.1016/j.compedu.2019.103657

Halim Tamuri, Ab. (2007). Islamic Education teachers' perceptions of the teaching of akhlāq in Malaysian secondary schools. Journal of Moral Education, 36(3), 371-386. https://doi.org/10.1080/03057240701553347

Kaufhold, M.-A., Bayer, M., \& Reuter, C. (2020). Rapid relevance classification of social media posts in disasters and emergencies: A system and evaluation featuring active, 
incremental and online learning. Information Processing \& Management, 57(1), 102132. https://doi.org/10.1016/j.ipm.2019.102132

Kimiloglu, H., Ozturan, M., \& Kutlu, B. (2017). Perceptions about and attitude toward the usage of e-learning in corporate training. Computers in Human Behavior, 72, 339-349. https://doi.org/10.1016/j.chb.2017.02.062

Lin, G.-Y. (2018). Anonymous versus identified peer assessment via a Facebook-based learning application: Effects on quality of peer feedback, perceived learning, perceived fairness, and attitude toward the system. Computers \& Education, 116, 81-92. https://doi.org/10.1016/j.compedu.2017.08.010

Mayer, R. E. (2019). Searching for the role of emotions in e-learning. Learning and Instruction, 101213. https://doi.org/10.1016/j.learninstruc.2019.05.010

Memon, N. (2011). What Islamic school teachers want: Towards developing an Islamic teacher education programme. British Journal of Religious Education, 33(3), 285-298. https://doi.org/10.1080/01416200.2011.595912

Pai, H.-C., Ko, H., Eng, C.-J., \& Yen, W.-J. (2017). The mediating effect of self-reflection and learning effectiveness on clinical nursing performance in nursing students: A follow-up study. Journal of Professional Nursing, 33(4), 287-292. https://doi.org/10.1016/j.profnurs.2017.01.003

Saada, N., \& Gross, Z. (2017). Islamic education and the challenge of democratic citizenship: A critical perspective. Discourse: Studies in the Cultural Politics of Education, 38(6), 807-822. https://doi.org/10.1080/01596306.2016.1191011

Sari, A. C., Fadillah, A. M., Jonathan, J., \& David Prabowo, M. R. (2019). Interactive Gamification Learning Media Application For Blind Children Using Android Smartphone in Indonesia. Procedia Computer Science, 157, 589-595. https://doi.org/10.1016/j.procs.2019.09.018

Stoetzel, L., \& Shedrow, S. (2020). Coaching our coaches: How online learning can address the gap in preparing K-12 instructional coaches. Teaching and Teacher Education, 88, 102959. https://doi.org/10.1016/j.tate.2019.102959

Talebian, S., Mohammadi, H. M., \& Rezvanfar, A. (2014). Information and Communication Technology (ICT) in Higher Education: Advantages, Disadvantages, Conveniences and Limitations of Applying E-learning to Agricultural Students in Iran. Procedia - Social and Behavioral Sciences, 152, 300-305. https://doi.org/10.1016/j.sbspro.2014.09.199

Tongkaw, A. (2013). Multi Perspective Integrations Information and Communication Technologies (ICTs) in Higher Education in Developing Countries: Case Study Thailand. Procedia - Social and Behavioral Sciences, 93, 1467-1472. https://doi.org/10.1016/j.sbspro.2013.10.065

Trainor, L. J. (2012). Predictive information processing is a fundamental learning mechanism present in early development: Evidence from infants. International Journal of Psychophysiology, 83(2), 256-258. https://doi.org/10.1016/j.ijpsycho.2011.12.008

Triyono, M. B. (2015). The Indicators of Instructional Design for E- learning in Indonesian Vocational High Schools. Procedia - Social and Behavioral Sciences, 204, 54-61. https://doi.org/10.1016/j.sbspro.2015.08.109

Vie, S. (2018). Effective Social Media Use in Online Writing Classes through Universal Design for Learning (UDL) Principles. Computers and Composition, 49, 61-70. https://doi.org/10.1016/j.compcom.2018.05.005 
Wibawa, A. S., \& Purwarianti, A. (2016). Indonesian Named-entity Recognition for 15 Classes Using Ensemble Supervised Learning. Procedia Computer Science, 81, 221-228. https://doi.org/10.1016/j.procs.2016.04.053

Yang, P. (2018). Compromise and complicity in international student mobility: The ethnographic case of Indian medical students at a Chinese university. Discourse: Studies in the Cultural Politics of Education, 39(5), 694-708. https://doi.org/10.1080/01596306.2018.1435600

Zainuddin, Z. (2018). Students' learning performance and perceived motivation in gamified flipped-class instruction. Computers \& Education, 126, 75-88. https://doi.org/10.1016/j.compedu.2018.07.003

\section{BIODATA PENULIS}

Mutmainnah Mustofa is a senior lecture at the Department of English, Universitas Islam Malang, East Java, Indonesia. She researches issues of character education and teacher professional development through poetry and literacy studies.

Rulam Ahmadi is a senior lecturer at the Department of Indonesian Language Education, Universitas Islam Malang, East Java Indonesia. He researches issues of language teaching methodology and literacy practices in higher education contexts.

Imam Wahyudi Karimullah lecturers at the Department of English, Universitas Islam Malang, East Java, Indonesia. He is interested in the issues of teaching and learning methodology. 